\title{
Teaching Reform in Higher Vocational College Accounting
}

\author{
Xi CHEN \\ QiLu University of Technology, No 58, Sangyuan Road, Jinan city, Shandong Province, China \\ chenxi801001@126.com
}

\begin{abstract}
Teaching Reform in Higher Vocational Accounting is an important part of education reform in our country, and how the quality of accounting education is directly related to the quality of future capabilities and the entire accounting accounting personnel. From the current social survey shows that the actual employment rate of graduates of vocational accounting is not optimistic, which to some extent reflects the accounting practices of vocational accounting teaching profession mistrust . Based on research, teaching vocational colleges accounting problems and social needs were analyzed, proposed the idea to build a new model of teaching reform of accounting in order to provide theoretical support for the further deepening of the future of accounting education reform.
\end{abstract}

Index Terms - Vocational colleges, Accounting education, Social needs, Reform model

Accounting is a technical application of strong economic management discipline, more economic growth, more important accounting. Therefore, accounting training teaching accounting Teachinsg indispensable content. The accounting profession as a traditional specialty in vocational education emerging pattern, whether it is educational theory, talent training mode, teaching content, teaching methods, methods and means are highlighted lag. To this end, the accounting reform teaching methods and means to strengthen the ability of students to acquire knowledge and innovative spirit, is to deepen the reform of vocational colleges teaching an important part of the accounting profession. Accounting vocational colleges training objectives should be: to enable students in moral, intellectual, physical, and aesthetic development, both to master the theoretical knowledge of accounting, economics and management knowledge, but also skilled use of financial accounting software for the actual operation of the junior college level advanced skills of the personnel. Therefore, research exploring vocational colleges teaching accounting reform is imminent.

\section{Investigation and Analysis Vocational Colleges Accounting Needs of the Community}

The group members started from July 2006 , conducted extensive research on the status of vocational accounting professional social needs, use the summer has visited more than 100 enterprises in Qingdao , Shanghai , Shantou, Shenzhen, Zhuhai and other coastal areas understand the basic requirements of the current enterprises accounting professionals and social needs of the situation. By finishing the survey showed that the number of the current social recruitment accounting profession ranked tenth, the number of candidates in the accounting profession in second place, but did not hire recruiters appropriate accounting talent, talent some kind of imbalance in supply and demand sides situation . Because the major companies are hiring accounting professionals have stated over two years post qualification experience in accounting or certified accountant, senior financial officers, accounting officers and require candidates, in addition to have accounting expertise, but also need to have the general ability such as quick thinking, analytical skills and interpersonal skills and practical ability. Accounting for graduates of a vocational, of course, to meet this requirement, therefore, the actual employment rate accounting graduate vocational colleges is not optimistic, which makes accounting teaching profession is facing an embarrassing situation, but also brought to our thinking and research .

\section{Vocational Colleges' Teaching In The Accounting Problems And Analysis}

\section{A. Accounting teaching objectives are not clear, consistent targeting}

Judging from the different training objectives existing accounting specialist vocational colleges of education , many vocational training objectives of the accountancy profession is either copied accounting training objectives of undergraduate education , the students as " accountant" or " senior specialists " and so on ; either think of vocational students are entrance students, inferior, can only do simple, repetitive work, not to mention what qualities and abilities, just have to learn basic accounting on the line, not to mention what the training objectives . Lack of in the end what kind of vocational training accounting personnel seriously, scientific research. Therefore, to establish a clear, practical teaching objectives in line with the accounting needs of the community is a priority. Otherwise, the curriculum arbitrary, unreasonable use of teaching methods, the accounting profession will inevitably lead to vocational training objectives difficult to achieve.

\section{$B$. The existence of the theoretical and practical issues in accounting disjointed Curriculum System}

Teaching programs in accounting, all the courses are divided into basic courses, professional courses and specialized courses at three levels, there is no escape systematic, discipline, integrity constraints of knowledge, not a copy vocational curriculum implementation curriculum model is replica of the undergraduate curriculum, there is not enough emphasis on practical ability of students to enable students to develop is difficult to adapt to the market economy, accounting personnel "multi-skill "," a dedicated multi-use ' diverse needs, just focus on accounting education classroom imparting knowledge, while ignoring the teaching of accounting training operation, causing the contents of the curriculum system reach the goal of accounting education requirements, it is difficult to meet the needs of the community employer . 


\section{Theoretical and practical teaching accounting practice treatment vary greatly, accounting theory and practice of light weight Teachers}

Affected traditional accounting teaching, teachers talk endlessly, students write a stop, blocking students' thinking, the only way to acquire knowledge of the memory as a student passive, is not conducive to improving the overall quality of students, teachers taught the students the theoretical knowledge, although , but ignored teach students how to apply this knowledge. Although students learn book knowledge, such as how accounting will be recorded, how the preparation of the report, but the actual accounting work in the face of business processes I do not know how to start, do not know how to use financial information to help solve these practical problems. Because many teachers have long been engaged in accounting theory teaching, lack of practical experience, and thus its practical teaching with a strong theoretical inevitably color.

\section{Single way of teaching, practical teaching accounting hardware lag}

Teaching methods include teaching methods and teaching methods, from the current accounting of vocational education, the teaching poorly equipped, backward teaching methods, teaching methods, a single situation remains universal. From the look of teaching methods, each vocational colleges common problem is a single " cramming " lecturing instead of teaching content further discussion and get to the bottom , this teaching method is not conducive to the mobilization of student learning initiative, enthusiasm and creativity not conducive to the cultivation of students' ability to think independently . From the look of teaching methods, many vocational colleges because of budget constraints, the environment is too restrictive, teachers still use "blackboard + chalk" and other traditional teaching methods, resulting in multimedia courseware did not play its due role. Since teaching hardware lag, and the lack of effective update, resulting in students' practical ability in school and get a real workout to improve, thus affecting the quality of work and teaching effectiveness throughout the accounting teaching.

\section{The construction of a new vocational colleges teaching reform of the accounting model conceived.}

\section{A. The accounting curriculum and the needs of society, in close contact Student Employment}

To enable students to better meet the needs of the employer, the employer truly qualified jobs, China's accounting profession vocational curriculum should be based on market needs and student employment situation to develop. Each school year should be amended accordingly and replaced. Whenever there is a new theory, new policies, new regulations, the teacher should be promptly put them into lectures inside, to avoid students theoretical knowledge learned in school out of touch with the needs of the community. In addition, schools should strengthen student financial software (UF, Kingdee), skilled office software, databases and other computer skills to master. Currently society attaches great importance to the employer vocational students specialized skills, to broaden employment channels students can take advantage of the school's teaching resources, encouragement and support students to participate in social examination. As obtain computerized card, certificate of accounting practitioners, computer grade certificate and Assistant Accountant card. While strengthening the assessment of students' ability to apply the knowledge, the use of accounting expertise and innovation, so that students learn in the classroom, homework and social research and other activities, the performance from my management, communication and cooperation with others , problem solving and application of modern technology capacity and other means, design and innovation .

\section{$B$. To enhance the ability to target the practice of teaching reform}

Accounting profession is a very practical expertise, in order to reflect the application of the accounting profession of vocational characteristics, to increase the proportion of practical lessons, practice sessions and strive to make lessons more than $40 \%$, for which plans to reform education in enough theoretical knowledge of basic accounting under the premise of increasing the proportion of practical training sessions. Meanwhile, we should strengthen the "double" teacher training, to this end, while requiring teachers to participate in continuing education in accounting officer, to the corporate exercise, on the other hand to introduce senior accountant, CPA as a part-time teacher of the school. Focus on strengthening students' practical skills courses operate, student internship skills integrated simulation operations and financial accounting skills to operate the software. Finally, contact established campus practice base, as a professional training base schools and hire accounting personnel with extensive experience in accounting instructor training students to do, so that students get practical training in the social front line.

\section{Establish the accounting profession and accounting education sector strong link mechanism}

Establish mechanisms accounting profession and contact the education sector should be possible to take advantage of third parties, such as government, academic organizations, should also support and training on behalf of the accounting profession - the accounting profession of civil organizations, such as the Institute of Chartered Accountants, Institute of Management Accountants, etc., and using a variety of methods based on this, to play professional organizations of civil functions of communication and exchange. Such as participation in the development of the accounting profession education evaluation system. Needs survey of enterprises, organizations and extensive academic exchanges, research activities. Strongly advocated the teaching profession to the corporate accounting, accounting firms and other part-time, while actively invite senior members of the accounting profession to participate in the teaching of accounting work. Thus on the one hand to make up for lack of school teachers' skills to ensure a high level of expertise in teaching, on the other hand strengthened the link between schools and the community, to maintain the flexibility of the structure of the school teachers, but also improves the comprehensive faculty 
quality. Therefore, the reform of vocational education has become the consensus of accounting theory and accounting practice accounting profession.

Currently, vocational education has increased from "large-scale, " to today's "content quality type", and vocational accounting profession is also a popular major, large number of students. How the quality of accounting education is directly related to the future of the entire accounting work capacity and quality of accounting personnel. Therefore, to explore vocational colleges teaching accounting reform, help provide theoretical support for the further deepening of reform in the future of accounting education, research and analysis of accounting shortage of teaching colleges, to improve teaching efficiency, and ensure the quality of teaching has an important guiding role.

\section{References}

[1] Chen Shaohua. On issues related to the reform of university teaching Accounting Accounting Research. 2003.10.

[2] Yang Youhong. twenty -first century accounting education Accounting Research .2000.8.

[3] Li Peigen. Regarding our overall concept of accounting education reform. Lanzhou Commercial College newspaper. 1999.4.

[4] Chen Jin wan establish programs to adapt to the 21st century, the development of the accounting profession needs a new system. Nanjing Aerospace University reported. 2000.1

[5] Li Yan. Accounting student employment new trend. Chinese Education Week .2006.2.

[6] Chi Rong. Exploration of Practical Teaching in Higher Accounting. .2003.2 